\title{
REDATING SHUIDONGGOU LOCALITY 1 AND IMPLICATIONS FOR THE INITIAL UPPER PALEOLITHIC IN EAST ASIA
}

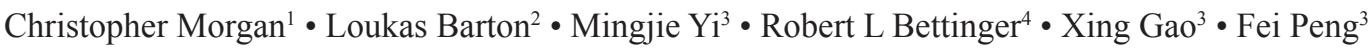

\begin{abstract}
A review of recently published temporal data from Shuidonggou Locality 1 indicates that a $40-43$ cal ka date for the inception of Initial Upper Paleolithic (IUP) blade-oriented technologies in East Asia is warranted. Comparison of the dates from Shuidonggou to other Asian IUP dates in Korea, Siberia, and Mongolia supports this assertion, indicating that the initial appearance of the IUP in East Asia generally corresponds in time to the fluorescence of the IUP in eastern Europe and western Asia. This conclusion preliminarily suggests that either a version of the IUP originated independently in East Asia just prior to $40 \mathrm{cal} \mathrm{ka}$, or more likely, that an early, initial diffusion of the IUP into East Asia occurred $\sim 41 \mathrm{cal} \mathrm{ka}$, a hypothesis consistent with current estimates for the evolution or arrival of modern humans in the region.
\end{abstract}

\section{INTRODUCTION}

In Asia, the Initial Upper Paleolithic (IUP) consists of behavioral innovations dating between approximately 41 and 28 cal ka that are distinguished in large part by the production of blades using Levallois or Levallois-like techniques and artifact assemblages exhibiting attributes of both Middle and Upper Paleolithic prepared-core reduction strategies (Kuzmin and Orlova 1998; Bar-Yosef and Kuhn 1999; Kuhn et al. 1999; Bar-Yosef 2007). Given this, the Asian IUP has not surprisingly been linked to both the European Middle Paleolithic (MP) and to the evolution or spread of anatomically modern humans, or at least modern human behaviors, in or into East Asia during the Late Pleistocene (Henshilwood and Marean 2003; Klein 2008; Norton and Jin 2009; but see Shea 2011). The IUP is consequently of considerable import to understanding the evolutionary and perhaps the demic relationships operating between Europe and Asia during the Late Pleistocene and to identifying how Upper Paleolithic (UP) behaviors proliferated across Eurasia between approximately 45,000 and 25,000 yr ago (Kuhn et al. 2004; Bar-Yosef and Wang 2012; Guan et al. 2012; Qu et al. 2013).

Given the materials that dominate most assemblages, it is not surprising that descriptions of the Eurasian IUP focus on lithic technologies. These have been termed, among others, lepto-Levalliosian (Kuhn 2004), which consists of blades struck from prepared cores that exhibit evidence of Levallois or prismatic reduction techniques, retouched blade tools, blade blanks showing extensive platform preparation, and elongate Levallois points. Some assemblages contain MP tool types like sidescrapers and denticulates. In others, tools more characteristic of the UP, such as endscrapers, burins, and truncations are present. Others contain both MP and UP tool types (Derevianko 1998; Kuhn et al. 1999). Descriptions of other behaviors are scant, save that hunting was likely a principal economic activity, and one that at least in some regions may have targeted more diverse prey species when compared to the preceding MP (Kuhn et al. 2009). Importantly, some see a temporal pattern in the distribution of IUP sites, with earlier dates further west, e.g. 52 cal ka at Boker Tachtit 1 in the Levant (Marks 1983), and later dates to the east, e.g. at Shuidonggou in China ( $34 \mathrm{cal} \mathrm{ka,} \mathrm{see} \mathrm{Liu}$ et al. 2009 and discussions below), with intermediate dates coming from locales like the Altai, e.g. Kara Bom at $46 \mathrm{cal} \mathrm{ka} \mathrm{(Goebel} \mathrm{et} \mathrm{al.} \mathrm{1993).} \mathrm{In} \mathrm{addition} \mathrm{to} \mathrm{a} \mathrm{dearth} \mathrm{of} \mathrm{preceding} \mathrm{Mousterian} \mathrm{deposits}$ in East Asia from which lepto-Levalliosian technologies might have developed, the IUP industries of northeast Asia are somewhat different than the IUP of western Eurasia (Brantingham et al. 2001, 2004). Together these observations may point to a separate origin for the IUP in northeast Asia, and a subsequent southward diffusion from Siberia to northern China via Mongolia (Brantingham et al. 2001, 2004). Yet the case is far from closed. Analysis of the latest published dates from Shuidong-

1. Department of Anthropology, University of Nevada, Reno,1664 N. Virginia St., Reno, Nevada 89557-0096, USA. Corresponding author. Email: ctmorgan@unr.edu.

2. Department of Anthropology, University of Pittsburgh, 3302 WWPH, Pittsburgh, Pennsylvania 15260, USA.

3. Institute of Vertebrate Paleontology and Paleoanthropology, Chinese Academy of Sciences, Beijing 100044, China.

4. Department of Anthropology, University of California-Davis, One Shields Ave., Davis, California 95616-8522, USA. 
gou and comparison of these to Eurasian IUP radiocarbon chronologies suggests, however, that either (1) IUP-bearing groups migrating from western Eurasia became temporarily established in East Asia on the order of 5000-11,000 yr earlier than is commonly accepted or (2) that prepared-core blade technologies developed independently in East Asia at about the same time as similar technologies were becoming established in eastern Europe and western Asia.

\section{SHUIDONGGOU LOCALITY 1}

In China's Ningxia Hui Autonomous Region, some $5 \mathrm{~km}$ south of the Yellow River, Shuidonggou $\left(38^{\circ} 17^{\prime} 55.0^{\prime \prime} \mathrm{N}, 106^{\circ} 30^{\prime} 6.2^{\prime \prime} \mathrm{E}\right)$ exhibits the easternmost expression of the IUP in Eurasia (Brantingham et al. 2004). The site consists of 12 localities spread along $6 \mathrm{~km}$ of incised Late Pleistocene and Holocene fluvial and lacustrine deposits containing cultural materials dating between, arguably, 35,900 and 6732 cal BP (Pei et al. 2012) (Figure 1). Locality 1 (SDG01) was the first discovered here, in 1923, and has a long research history, though its connection to "evolved Mousterian" and "emergent Aurignacian," and hence to the European MP and UP, was noted from the start (Licent and Chardin 1925; Boule et al. 1928; Bordes 1968). The most substantial work at Locality 1 occurred in 1980, when the Ningxia Hui Autonomous Region's Institute of Archaeology excavated a 15-m-deep trench that resulted in the stratigraphic section evident at the locality today (Ningxia Museum 1987; Ningxia Provincial Institute of Archaeology 2003). The upper $8 \mathrm{~m}$ of this section are still visible; the lowest strata are now buried in fill (Figure 2). More recent studies focus on re-interpreting the locality's stratigraphy and artifact assemblages, noting that SDG01 contains some of the oldest cultural deposits at the greater Shuidonggou site as a whole, making it critical to understanding the inception of the IUP and UP in East Asia (Chen et al. 1984; Li et al. 1987; Sun and Zhao 1991; Gao et al. 2008; Liu et al. 2009; Wang et al. 2009; Guan et al. 2011; Peng et al. 2012).



Figure 1 Map of the 12 localities comprising the Shuidonggou site 


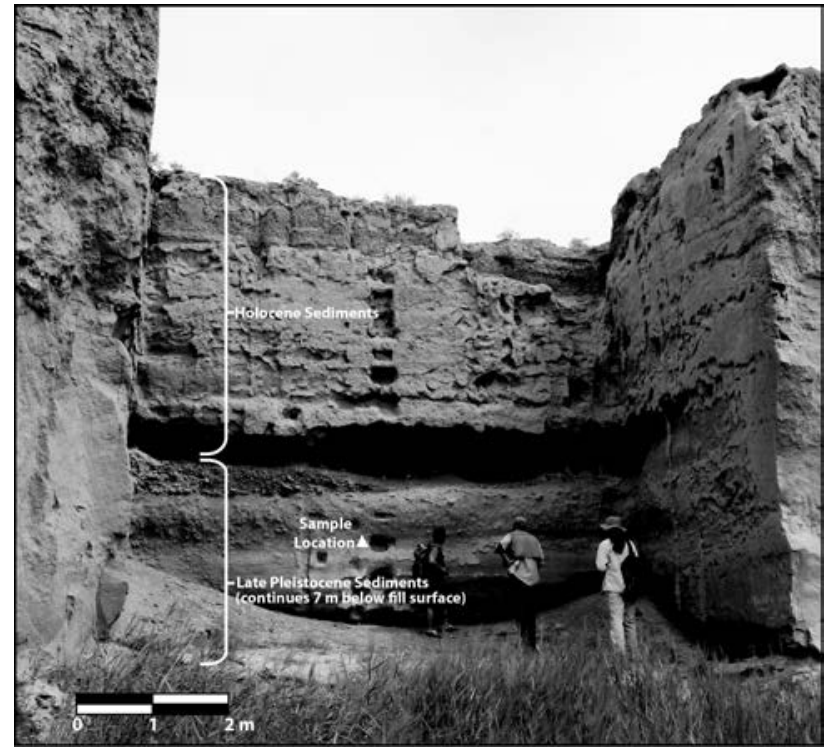

Figure 2 A 2011 photograph of SDG01 showing Holocene and Pleistocene stratigraphy and 2011 AMS sample location (Photo: C Morgan).

The locality contains Holocene and Late Pleistocene cultural deposits, the latter identified by five strata (i.e. Strata 3-7) (Liu et al. 2009; Pei et al. 2012). Earlier interpretations (Madsen et al. 2001), however, identify three Pleistocene strata (strata 6-8, the latter subdivided into substrata $8 \mathrm{a}, 8 \mathrm{~b}$, and $8 \mathrm{c})$. Determining the correspondence between these two basic interpretations is hampered by differences in description, scale (or lack thereof), and resolution of each reported profile, but the general sequence of each is equivalent (Figure 3). Using the earlier profile (reported in Brantingham et al. 2001 and Madsen et al. 2001), however, it is clear that the majority of the Pleistocene cultural materials are from Stratum 8b; strata 6 and 7 contain likely redeposited Pleistocene artifacts (Madsen et al. 2001). These artifact-bearing strata roughly correspond to strata 3, 4, 5, and 6 (also named the lower cultural level [LCL]) in Liu et al. (2009), Pei et al. (2012) and Li et al.'s (2013) more recent syntheses. Li et al. (2013) further subdivide the LCL into LCL layers A and B, with LCL A roughly corresponding to Liu et al.'s (2009) Layer 3 and LCL B roughly corresponding to layers 4, 5, 6, and 7. Importantly, cultural materials recovered from the Pleistocene strata consist of over 5500 artifacts made mainly on locally available quartzite and silicified alluvial clasts and more rarely on smaller cryptocrystalline pebbles. These include a relatively high frequency of side scrapers and denticulate tools that are more characteristic of the MP, but also prepared flat-faced blade cores, blades and blade tools, truncated blades, and unifacially retouched points made on blades or triangular flakes that are generally consistent with descriptions of other Eurasian lepto-Levalliosian/IUP assemblages (Brantingham et al. 2001:743-44).

Prior to 2012, there were three ${ }^{14} \mathrm{C}$ dates for SDG01's Pleistocene strata that ranged from 16,760 to $40,000{ }^{14} \mathrm{C}$ BP (Liu et al. 2009). Seven OSL dates for these lower strata compare favorably to the ${ }^{14} \mathrm{C}$ dates; these range from 15,800 to 35,700 BP (Table 1). Clear in this distribution of dates, however, is that dating the lower, Pleistocene strata at SDG01 - those containing the earliest evidence of the IUP in East Asia-is problematic. There are several stratigraphic reversals (e.g. between Liu et al.'s layers 4 and 5), suggesting either stratigraphic mixing or methodological errors, leaving the conundrum of which date(s) legitimately represent human use of the locality. 


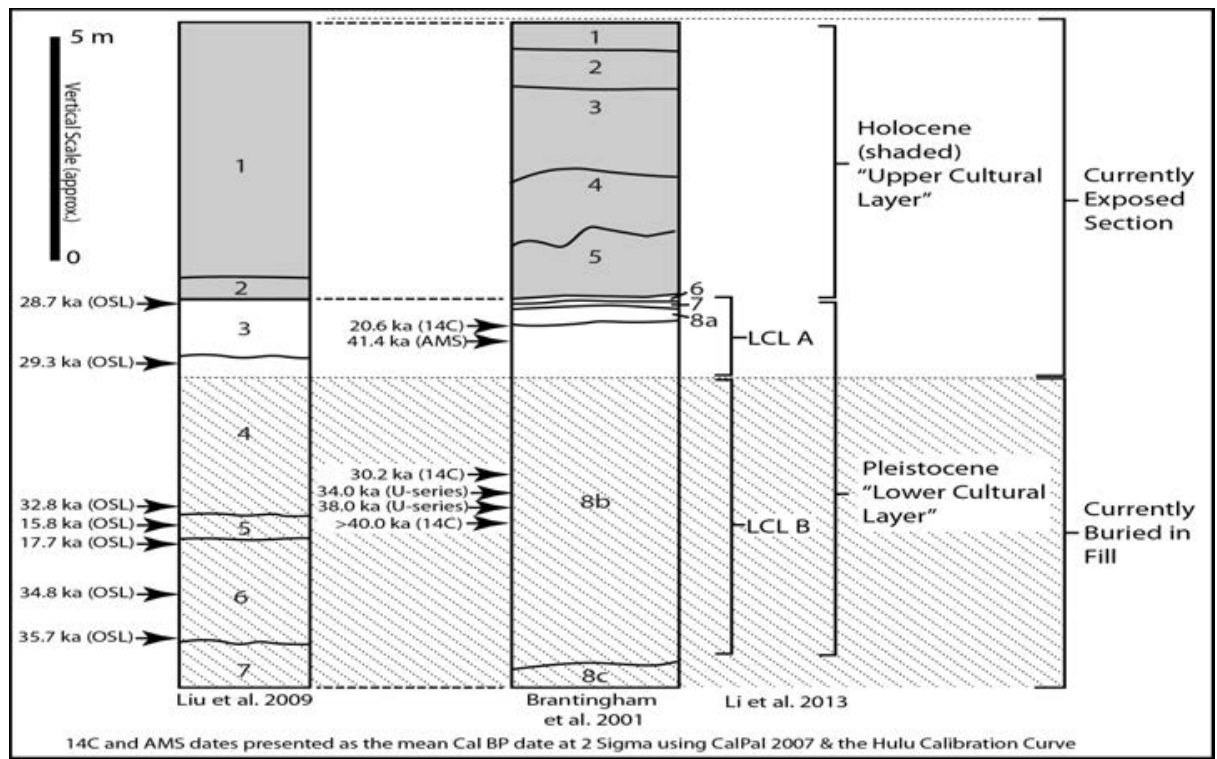

Figure 3 Comparison of SDG01 stratigraphic interpretations showing associated dating results

Table 1 Dating results for the Late Pleistocene strata at Shuidonggou 1.

\begin{tabular}{|c|c|c|c|c|c|c|c|}
\hline Stratum $^{1}$ & Stratum $^{2}$ & Sample & Material & Method & Lab date $^{3}$ & Range cal $\mathrm{BP}^{4}$ & Citation \\
\hline \multirow[t]{2}{*}{3} & & S1-3 & Sediment & OSL & $28,700 \pm 6000$ & $22,700-34,700$ & Liu et al. 2009 \\
\hline & $7-8 \mathrm{a}$ & PV-331 & Bone & ${ }^{14} \mathrm{C}$ & $\begin{array}{l}16,760 \pm 210 \\
{ }^{14} \mathrm{C} \mathrm{BP}\end{array}$ & $19,600-20,640$ & CQRA 1987 \\
\hline 4 & & S1-4 & Sediment & OSL & $29,300 \pm 4100$ & $25,200-33,400$ & Liu et al. 2009 \\
\hline 4 & & S1-5 & Sediment & OSL & $32,800 \pm 3000$ & $29,800-35,800$ & Liu et al. 2009 \\
\hline 5 & & S1-6 & Sediment & OSL & $15,800 \pm 1100$ & $14,700-16,900$ & Liu et al. 2009 \\
\hline \multirow[t]{3}{*}{6} & & S1-7 & Sediment & OSL & $17,700 \pm 900$ & $16,800-18,600$ & Liu et al. 2009 \\
\hline & $8 \mathrm{~b}$ & PV-317 & Carbonate & ${ }^{14} \mathrm{C}$ & $\begin{array}{l}25,450 \pm 800 \\
{ }^{14} \mathrm{C} \mathrm{BP}\end{array}$ & $29,546-30,910$ & Li et al. 1987 \\
\hline & $8 b$ & BKY82042 & Equus tooth & U-series & $34,000 \pm 2000$ & $32,000-38,000$ & Chen et al. 1984 \\
\hline 6 & & S1-8 & Sediment & OSL & $34,800 \pm 1500$ & $33,300-36,300$ & Liu et al. 2009 \\
\hline \multirow[t]{2}{*}{6} & & S1-9 & Sediment & OSL & $35,700 \pm 1600$ & $34,100-37,300$ & Liu et al. 2009 \\
\hline & $8 b$ & 82042 & Equus tooth & U-series & $38,000 \pm 2000$ & $34,000-42,000$ & Chen et al. 1984 \\
\hline 3 & $8 b$ & UGAMS-9682 & Charcoal & AMS & $36,200 \pm 140$ & $41,009-41,728$ & $\begin{array}{l}\text { Peng et al. } 2012 \\
\text { and this report }\end{array}$ \\
\hline 6 & & Not reported & Silt sediment & ${ }^{14} \mathrm{C}$ & $>40,000{ }^{14} \mathrm{C} \mathrm{BP}$ & $\mathrm{n} / \mathrm{a}$ & $\begin{array}{l}\text { Geng and Dan } \\
1992\end{array}$ \\
\hline
\end{tabular}

${ }^{1}$ Per Liu et al. (2009) and Pei et al. (2012); ${ }^{2}$ Per Madsen et al. (2001) and Brantingham et al. (2001); ${ }^{3}$ Dates are in calendar years before present, unless otherwise noted; ${ }^{14} \mathrm{C}$ dates calibrated at $2 \sigma$ with CalPal-2007 (Weninger et al. 2012) using the Hulu calibration curve. 
However, there is some patterning to these chronometric problems (Table 1; Figure 3). First, OSL dates, save one each in Liu et al.'s (2009) layers 5 and 6, appear generally older with depth, suggesting some consistency in OSL results; the two younger dates in layers 5 and 6 that result in reversals could conceivably indicate problems with determining soil moisture or dose rate in the fluvial-lacustrine sediments that characterize these layers (Murray and Olley 2002; Liu et al. 2009). Second, two of the ${ }^{14} \mathrm{C}$ dates appear markedly young compared to most of the OSL dates and result in substantial reversals. Importantly, these dates were derived from bone collagen and a carbonate nodule, leading Madsen et al. (2001:707) to assert that these dates should be considered at best minimum ages due to problems associated with deriving accurate ${ }^{14} \mathrm{C}$ dates from these types of materials. Both Madsen (2001) and Gao et al. $(2002,2008)$ consequently discount these dates, which seems reasonable, particularly with regard to the substantial reversal generated by the youngest, $16,760{ }^{14} \mathrm{C}$ date $(\mathrm{PV}$ 331). The oldest ${ }^{14} \mathrm{C}$ date, at $>40,000{ }^{14} \mathrm{C} \mathrm{BP}$, however, roughly corresponds to the uranium series dates. The $\mathrm{U}$ series dates generally appear older than either the OSL or ${ }^{14} \mathrm{C}$ dates, leading previous researchers to suggest caution in their acceptance (Brantingham et al. 2001) or a tendency towards discounting them as well (Liu et al. 2009), both perspectives taking into account the methodological problems associated with U series dates derived from bones and teeth (Chen and Yuan 1988; Rae et al. 1989; Millard and Hedges 1995; Pike and Hedges 2001). In sum, dating the Pleistocene strata at SDG01 is confounded by old and methodologically problematic U series dates, enough reversals to suggest OSL dates should be interpreted with caution, and inconsistently young ${ }^{14} \mathrm{C}$ dates that at best might be considered minimum dates for occupation of the locality, or discarded entirely. Despite the increasing use of OSL, ${ }^{14} \mathrm{C}$ age estimation is still the standard in archaeological dating and the most amenable for comparison with dates from other Eurasian IUP sites (Goebel 2004; Jöris et al. 2011). In any event, in light of the data discussed above, Pei et al. (2012) cautiously assess the earliest dates from all Shuidonggou localities, concluding that the earliest, i.e. the maximum, legitimate dates for SDG01 are around 25,000 cal BP, a period mostly in agreement with earlier research wary of accepting the earlier dates at the locality (Brantingham et al. 2001; Madsen et al. 2001), but also corresponding to the minimum ${ }^{14} \mathrm{C}$ date derived from a carbonate nodule from SDG01. Clearly, additional dating efforts were required.

\section{FIELD STUDIES}

With this context in mind, the locality was inspected to determine whether ${ }^{14} \mathrm{C}$-datable materials amenable for comparison to the locality's OSL dates were present in the section. Close examination identified several small flecks of charcoal in the upper portion of Stratum $8 \mathrm{~b}$ (per Madsen et al. 2001), which roughly corresponds to Liu et al.'s (2009) Stratum 3 and Li et al.'s (2013) LCL Aessentially the upper portion of the main IUP artifact-bearing strata at the locality. Sediments in this stratum consist mainly of blocky silts (Liu et al. 2009). These lie $75 \mathrm{~cm}$ beneath a distinct 30 -cm-thick fluvial facies containing abundant sands, gravels, and small cobbles corresponding to Brantingham et al.'s (2001) Stratum 7 (Figures 2 and 3). The charcoal fragments are all extremely small $(<5 \mathrm{~mm}$ in length) and deeply embedded within in situ sediments. One charcoal sample (originally reported but not described in Pei et al. 2012) from a cleaned portion of the section was collected and mapped into the section (Figure 3). The sample was dated at the University of Georgia Center for Applied Isotope Studies (lab code UGAMS) using the AMS method described in Vogel et al. (1984). The sample (UGAMS-9682) returned a date of $36,200 \pm 140{ }^{14} \mathrm{C} B P\left(\delta^{13} \mathrm{C}=-23.1\right)$, calibrated at $2 \sigma$ to $41,009-41,728$ cal BP using CalPal-2007 (Weninger et al. 2012) and the Hulu calibration curve (Weninger and Jöris 2008) (Table 1). CALIB 6.1.0 (Stuiver and Reimer 1993) and the IntCal09 curve (Reimer et al. 2009) return the exact same results at $2 \sigma$. 


\section{DISCUSSION}

The striking thing about a 41 cal ka date for an IUP deposit in East Asia is, of course, its considerable age and the fact that it temporally corresponds to many other IUP sites across Eurasia (Kuzmin and Orlova 1998; Goebel 2004), as well as the U series dates from the basal cultural layers at the SDG01 locality. Problematic, however, is the stratigraphic reversal this date generates when compared to the locality's OSL chronology: it is over 10,000 yr older than the two OSL dates bracketing the sample. This difference, however, is reduced to as little as $6300 \mathrm{yr}$ when considering the $4100-6000$ yr error ranges associated with these two OSL dates. In fact, discounting the two certainly too-young 15.5-17.7 ka OSL dates in Liu et al.'s (2009) strata 5-6, the OSL dates in SDG01's IUP strata range from approximately $30-37 \mathrm{ka}$, younger than, but not appreciably so given the time depth and error ranges involved, the older U series dates and the new AMS date for the locality. This correspondence between older dates at the locality suggests that a maximum 37-41 cal ka date for the IUP deposits at the locality is not unreasonable (see also Li et al. 2013), though cautiously so, per Pettit et al. (2003) and Graf (2008).

Though based on only one new date, the correspondence of the early dates at Shuidonggou to other IUP ${ }^{14} \mathrm{C}$ chronologies is intriguing enough to warrant reconsideration of the relationship between the East Asian and western Eurasian IUP. To accomplish this, a database was generated listing all published IUP sites in Europe and Asia (see Appendix S1, online Supplementary file; and Figure 4). Listing on the database is based on technological descriptions conforming to those of the IUP and by outright identification as IUP, Early Upper Paleolithic, lepto-Levalloisian, Bohunician, or Emirian in the primary sources for each site (cited in the database itself). It is also based on evaluation of secondary sources and critical reviews of IUP sites across Eurasia. For Europe, these latter sources include Svoboda (2004), Hedges et al. (1994), Meignen et al. (2004), Richter et al. (2008), and Vishnyatsky and Nehoroshev (2004). For western Asia and the Levant, the sources are Goring-Morris et al. (2005) and Kuhn et al. (2004, 2009); for Siberia and Mongolia, these are Brantingham et al. (2001), Derevianko et al. (2005), Derevianko (1998), Goebel (1993, 2004), Jöris et al. (2011), Kuzmin (2004), and Kuzmin and Orlova (1998). For East Asia, sources overlap with Siberian and Mongolian ones and also include Bae and Kim (2010), Bae and Bae (2012), Li et al. (2013), Liu et al. (2009), Pei et al. (2012), and Seong (2011).

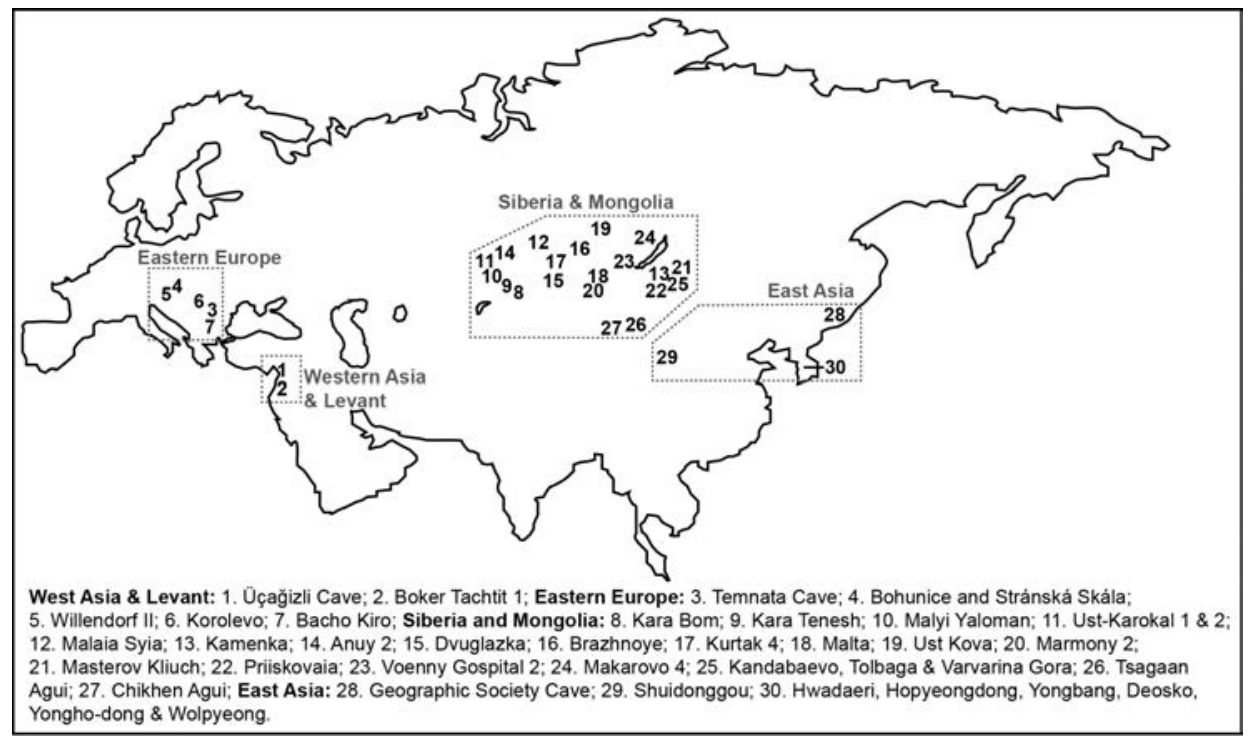

Figure 4 Map of mainland Eurasia showing IUP sites from Appendix S1 and geographic groupings 
Reviewing these data, at Shuidonggou Locality 2, a recently reported 41,570 cal BP AMS date (Liu et al. 2009) from the lower level of the IUP-bearing strata there corresponds to the older dates at SDG01. In Korea, there is increasing (though tentative) evidence of blade manufacture and other IUP-type industries in the older ${ }^{14} \mathrm{C}$ dates from sites like Yongbang, Wolpyeong, Deosko, and Yongho-dong 39-43 cal ka (Bae and Kim 2010; Seong 2011). In northern Asia, at least 24 older ${ }^{14} \mathrm{C}$ dates associated with IUP-bearing strata at sites like Kara Bom, Malaia Syia, Tsagaan Agui, and Varvarina Gora range from about 37-46 cal ka (Kuzmin 2004). In eastern Europe, $32{ }^{14} \mathrm{C}$ dates ranging from 37-46 cal ka are associated with Bohunician and other lepto-Levalliosian components at sites like Brno-Bohunice and Stránská skála (Richter et al. 2008; but see Higham 2011). Finally, in Turkey $8{ }^{14} \mathrm{C}$ dates from Üçağizli Cave range from 38-44 cal ka (Kuhn et al. 2009). (The earliest dates from Boker Tachtit 1 were generated in the early 1980s and should be evaluated with considerable caution; nonetheless, later ones generally overlap with those at Üçağizli Cave.) In sum, at least $73{ }^{14} \mathrm{C}$ dates (including 9 from East Asia and 24 from North Asia) suggest that between roughly 37 and $46 \mathrm{cal} \mathrm{ka}$ people across Eurasia began using blade technologies incorporating characteristics of MP and UP technocomplexes.

This picture is further refined by considering the summed probability distributions for the IUP ${ }^{14} \mathrm{C}$ dates in Appendix S1. Though inferring occupational histories with these methods is certainly prone to debate (Williams 2012), these methods provide a way of interpreting large sets of dates-as-data while recognizing the curves they generate can be skewed due to biases entailed by the stratigraphy, presence or absence of features, sampling methods, and even funding available to different researchers at diverse archaeological sites across broad geographic expanse (Anderson et al. 2011; Steele 2010). Recognizing this, this study opts for a simple yet methodologically transparent approach where each ${ }^{14} \mathrm{C}$ date is afforded equal weight in the summed probability distribution. While this may introduce sampling bias at sites where many dates were generated from single features or strata, it eliminates the sacrifice of accuracy for increased precision entailed by post-hoc statistical manipulation of ${ }^{14} \mathrm{C}$ dates (Steier and Rom 2000; Bronk Ramsey 2009; Weninger et al. 2011). It is also consistent with the straightforward (albeit controversial) perspective that, especially with large data sets, more human activity and more people operating in past contexts increase the likelihood of recovering and dating carbon resulting from their activity and are therefore useful as general visual indicators of past population histories (Gamble et al. 2005; Shennan and Edinborough 2007; Bamforth and Grund 2012).

Within this methodological context, summed probability distributions were generated for each of the four regions described above by pooling $131{ }^{14} \mathrm{C}$ dates in Appendix S1 (dates without published standard deviations were not included in the analysis) and again using CalPal-2007 (Weninger et al. 2012 ) and the Hulu calibration curve (Weninger and Jöris 2008) to generate $1 \sigma$ summed probability distributions for each region (methodological description in Buchanan et al. 2008 and van Andel et al. 2003) (Figure 5). CalPal-2007 was used because it does not contain a smoothing algorithm to produce summed probability curves (as does, for example, CALIB 6.1), meaning the curves it generates more accurately represent the probabilities derived from the ${ }^{14} \mathrm{C}$ data (Buchanan et al. 2011) and are thus more applicable to the goals of the current study (per van Andel 2005). The Hulu curve is the most recent curve contained in the CalPal-2007 software.

Upon inspection, four main trends stand out. First, it is clear the IUP in southwestern Asia and eastern Europe is contemporaneous and fairly short-lived, spanning roughly 11,000 yr between 46 and $35 \mathrm{cal} \mathrm{ka}$ (the pre-46 cal ka dates from the Levant result from the problematic dates from 
Figure 5 Summed probability distributions of Eurasian IUP sites by geographic grouping.

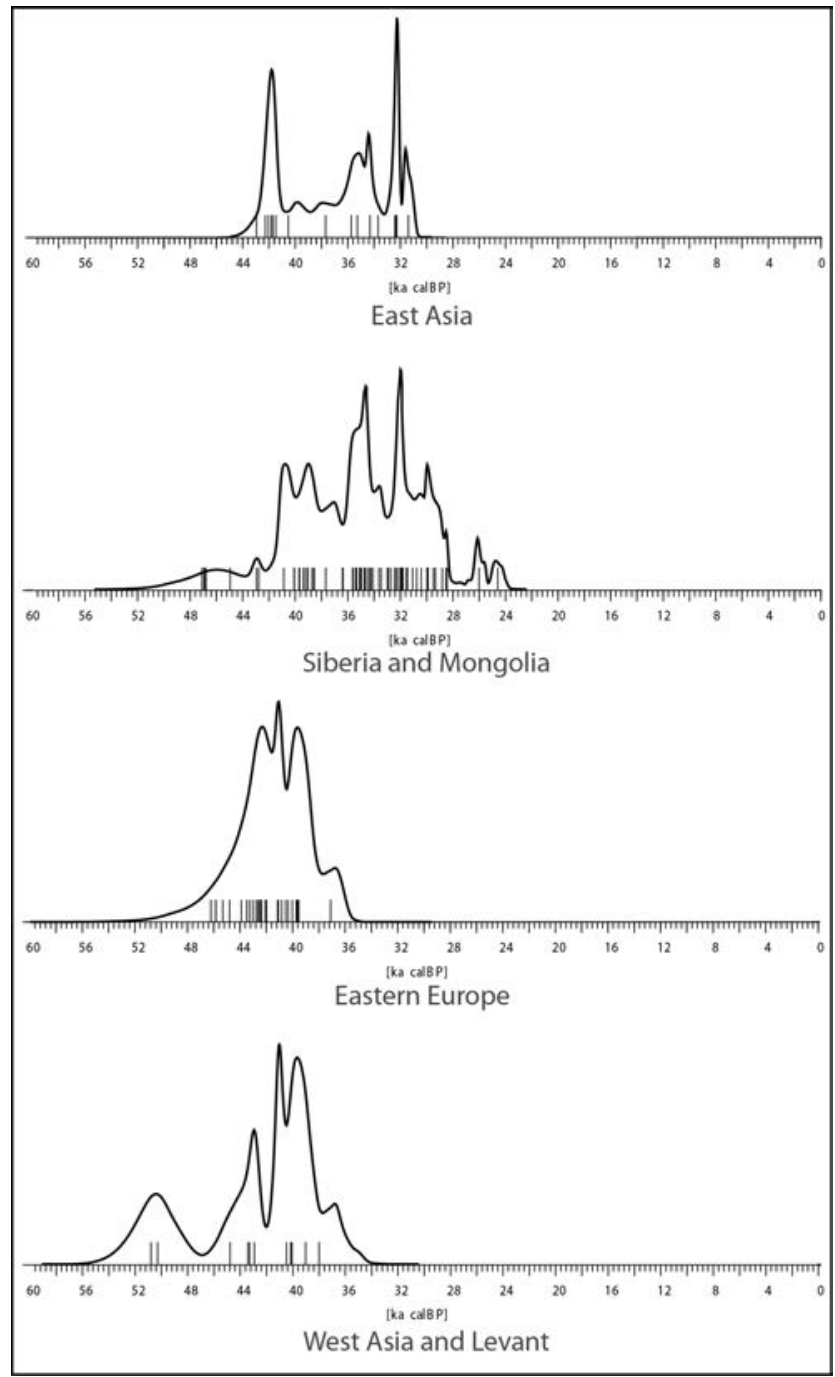

Boker Tachtit 1). Second, the North and East Asian IUP spans nearly twice this period of time (i.e. 23,000 yr from 47-24 cal ka, with most dates, however, falling in the 44-28 cal ka span). Third, though there is substantial temporal overlap, the North and East Asian curves are for the most part younger, on average by more than 7000 yr, than the western Eurasian ones. Lastly, more pronounced multimodal curves for China, Korea, Siberia, and Mongolia contrast with those for eastern Europe and southwestern Asia, suggesting perhaps more complex IUP histories.

These observations have important implications regarding the nature of IUP adaptations and the evolutionary relationships operating between Europe and Asia during the IUP. Superficially, the generally younger dates in North and East Asia might seem to support the hypothesis that the IUP is late and intrusive there and may have been brought into the region by modern humans, a reconstruction in line with much genetic evidence and ideas about the establishment of modern humans across Eurasia (Cann et al. 1987; Chu et al. 1998; Ingman et al. 2000; Su et al. 2000; Zhang et al. 2007; Klein 2008). But the overlap in probability distributions between 44 and 40 cal ka, particularly between East Asia and western Eurasia, suggests two alternatives. The first maintains the diffusion- 
ist-migratory perspective of the preceding, but notes that the trajectory of the IUP in East Asia is characterized by an initial, isolated, and distinctive peak in ${ }^{14} \mathrm{C}$ probabilities, suggesting perhaps an early but ultimately unsuccessful colonization of the region about $41-43$ cal ka by European/West Asian populations who introduced blade-based technologies to an East Asia dominated for so long by simple core-flake ones more characteristic of the Lower Paleolithic (Gao and Norton 2002). In this scenario, these behaviors would then have been reintroduced $\sim 36$ cal ka by already well-established Siberian and Mongolian IUP groups who either migrated into East Asia or introduced IUP technologies via trade or some other medium of cultural transmission (e.g. Zam'atnin 1951; Bae and Kim 2010; Bae and Bae 2012). The second alternative considers the hypothesis developed by Seong $(2006,2009)$, who argues that blade-based technologies commensurate with the IUP developed in situ in East Asia on the order of $40 \mathrm{cal} \mathrm{kyr} \mathrm{ago} \mathrm{(see} \mathrm{also} \mathrm{a} \mathrm{similar} \mathrm{argument} \mathrm{by} \mathrm{Derevianko}$ et al. 1998 positing that the Siberian and Mongolian IUP evolved directly from the preceding late Mousterian). He bases this argument on new dates from six early Upper Paleolithic sites on the Korean Peninsula, each of which contains at least some evidence of blade manufacture. These dates of course also correspond to the oldest IUP dates from Shuidonggou and from Geographic Society Cave, in the Russian Far East (Figure 4).

Evaluating these hypotheses, we argue the older, $41 \mathrm{cal}$ ka dates from Shuidonggou are legitimate and that these are clearly associated with lepto-Levalloisian/IUP assemblages. However, the number of blades and prepared blade cores recovered from Korean contexts is small and associated not only with denticulates and endscrapers characteristic of the MP, UP, and IUP, but also with distinctive tanged points associated solely with the Korean UP (Seong 2008, 2009, 2011). The apparent uniqueness of the Korean IUP might consequently argue for in situ development (or perhaps a localized variant of the Eurasian IUP); the case in China is less clear. The absence of a preceding East Asian MP from which the MP tool types and blades found in IUP components might be derived (Gao and Norton 2002) continues to vex arguments for in situ technological evolution, yet the sheer distances involved and the relatively narrow frame of years for which the IUP to have diffused or have been brought by migrating groups across Eurasia might, at least on the surface, argue for in situ development. Though some researchers seem to imply that the IUP at Shuidonggou is either closely associated with or perhaps derived from the IUP in either Mongolia or Siberia (Brantingham et al. 2001,2004 ) it is worth noting that $\sim 6100 \mathrm{~km}$ separates Shuidonggou from Üçağizli Cave, the latter one of the earliest and best examples of the IUP in West Asia (Kuhn 2004; Kuhn et al. 1999, 2004, 2009 ) and that the earliest dates at each are separated by about $3400 \mathrm{yr}$ (41.5 cal ka at Shuidonggou and $44.9 \mathrm{cal} \mathrm{ka}$ at Üçağizli Cave). Given this, a migration rate of just $1.8 \mathrm{~km} / \mathrm{yr}$ would allow for either migration or diffusion to account for the presence of IUP technologies at Shuidonggou, a rate certainly within the range of even the most conservative data on hunter-gatherer yearly residential moves (Binford 2001:270-5) and in line with rates of migration for humans into unoccupied territory (Anderson and Gillam 2000; O'Connell and Allen 2004). Given this, it seems plausible that there was an early, pre-40 cal ka intrusion of the IUP into East Asia prior to the firm establishment of the IUP across East Asia $\sim 36$ cal ka.

Though based on only a handful of dates from Shuidonggou, some of them problematic, this assertion is bolstered by recent research some $380 \mathrm{~km}$ south of Shuidonggou, on Gansu Province's Western Loess Plateau (WLP), where excavations at the Dadiwan site and surveys and test excavations in the surrounding countryside have revealed a rich Paleolithic sequence tracking behavioral change through the late Pleistocene. At Dadiwan, where temporal control is maintained by 19 AMS and 7 OSL dates, a 10-m-deep deposit tracks variability in lithic technology and site use from $\sim 80$ cal ka to the Holocene. Importantly, the most intensive Paleolithic use of the site, marked by the highest densities of simple flake-and-shatter quartz technology, occurs 33-42 cal ka (Bettinger et al. 2010a,b; 
Zhang et al. 2010). Surveys and sampling in the surrounding countryside reveal a comparable pattern: of 63 Paleolithic sites identified in a roughly $20-\mathrm{km}$ radius around Dadiwan, 32 were dated using AMS, OSL, and position relative to distinctive, time-sensitive paleosol sequences (Chen et al. 1997, 1999). Of these, 19 (59\%) date between 30 and $45 \mathrm{cal}$ ka. Analyses of site distributions and artifacts recovered from these sites indicates that the diversity of exploited environments was greatest during this period of time and that there are significantly more deliberately manufactured flakes and retouched tools compared to shatter-dominated, earlier assemblages (Morgan et al. 2011). Though equivocal about associating these changes with modern humans or ostensibly UP modern human behaviors (Bettinger et al. 2010b), Morgan et al. (2011) hypothesize that the intensive, diverse, and arguably more technologically sophisticated behaviors that developed on the WLP between 45 and 30 cal ka might be consistent with an intrusion of modern humans, or at least modern human behaviors into the region. Though at this point the evidence is mostly circumstantial, the contemporaneity of these changes with evidence for the presence of the IUP at Shuidonggou $\sim 41$ cal ka suggests this may indeed be the case. Though the topic of modern human origins in China is remarkably contentious (Wu 2004), such an earlier intrusion would be consistent with most estimates for the arrival or evolution of modern human behaviors in the region, but it would also not necessarily preclude the possibility of IUP behaviors developing within the mosaic of human species apparently present across Eurasia during this time (Mellars 1999; d'Errico 2003; Reich et al. 2011), nor does it necessarily argue for the essentialist association of the Asian IUP with anatomically modern humans (Shea 2011).

\section{CONCLUSION}

To conclude, there is increasing evidence of IUP behaviors developing in East Asia $\sim 41$ cal ka that is contemporaneous with the proliferation of similar behaviors in western Asia and eastern Europe. Recently published dates from Shuidonggou provide additional data supporting this assertion. This contemporaneity suggests the alternatives that either the intrusion of the IUP into East Asia occurred earlier than previously recognized, arguably failing shortly after its introduction and reintroduced some $4000 \mathrm{yr}$ later, or that the East Asian IUP developed independently from the western Eurasian IUP. Though far from foregone conclusions - it is clear much more analysis and precision dating needs to be conducted at IUP sites across Eurasia to assess these hypotheses - the data presented herein suggest the former: that an early intrusion of the IUP occurred in East Asia 41 cal ka.

\section{ACKNOWLEDGMENTS}

We thank Wang Huimin from the Ningxia Province Institute of Archaeology, the faculty and staff of Institute of Vertebrate Paleontology and Paleoanthropology in Beijing, Utah State University students Lukas Trout and Colby Page, and the city of Yinchuan for their hospitality and support of this project. Project funded by University of California-Davis, the University of Pittsburgh, and Utah State University.

\section{REFERENCES}

Anderson DG, Gillam JC. 2000. Paleoindian colonization of the Americas: implications from an examination of physiography, demography, and artifact distribution. American Antiquity 65(1):43-66.

Anderson DG, Goodyear AC, Kennett J, West A. 2011. Multiple lines of evidence for possible human population decline/settlement reorganization during the Early Younger Dryas. Quaternary International 242(2):570-83.
Bae CJ, Bae K. 2012. The nature of the Early to Late Paleolithic transition in Korea: current perspectives. Quaternary International 281:26-35.

Bae CJ, Kim JC. 2010. The Late Paleolithic-Neolithic transition in Korea: current archaeological and radiocarbon perspectives. Radiocarbon 52(2):493-9.

Bamforth DB, Grund B. 2012. Radiocarbon calibration curves, summed probability distributions, and Early Paleoindian population trends in North America. 
Journal of Archaeological Science 39(6):1768-74.

Bar-Yosef O. 2007. The archaeological framework of the Upper Paleolithic revolution. Diogenes 54(2):3-18.

Bar-Yosef O, Kuhn SL. 1999. The big deal about blades: laminar technologies and human evolution. American Anthropologist 101(2):322-38.

Bar-Yosef O, Wang Y. 2012. Paleolithic archaeology in China. Annual Review of Anthropology 41:319-35.

Bettinger RL, Barton L, Morgan C. 2010a. The origins of food production in north China: a different kind of agricultural revolution. Evolutionary Anthropology 19(1):9-21.

Bettinger RL, Barton L, Morgan C, Chen F, Wang H, Guilderson TP, Ji D, Zhang D. 2010b. The transition to agriculture at Dadiwan, People's Republic of China. Current Anthropology 51(5):703-14.

Binford LR. 2001. Constructing Frames of Reference: An Analytical Method for Archaeological Theory Building Using Hunter-Gatherer and Environmental Data Sets. Berkeley: University of California Press.

Bordes F. 1968. The Old Stone Age. New York: McGraw-Hill.

Boule M, Breuil H, Licent E, Chardin PTD. 1928. Le Pa leolithique de la Chine. Paris: Archives de l'Institut de Paléontologie Humaine.

Brantingham PJ, Krivoshapkin AI, Jinzeng L, Tserendagva Y. 2001. The Initial Upper Paleolithic in Northeast Asia. Current Anthropology 42(5):735-47.

Brantingham PJ, Gao X, Madsen DB, Bettinger RL, Elston RG. 2004. The Initial Upper Paleolithic at Shuidonggou, northwestern China. In: Brantingham PJ, Kuhn SL, Kerry KW, editors. The Early Upper Paleolithic Beyond Western Europe. Los Angeles: University of California Press. p 233-41.

Bronk Ramsey C. 2009. Bayesian analysis of radiocarbon dates. Radiocarbon 51(1):337-60.

Buchanan B, Collard M, Edinborough K. 2008. Paleoindian demography and the extraterrestrial impact hypothesis. Proceedings of the National Academy of Sciences of the USA 105(33):11,651-4.

Buchanan B, Hamilton M, Edinborough K, O'Brien MJ, Collard M. 2011. A comment on Steele's (2010) "Radiocarbon dates as data: quantitative strategies for estimating colonization front speeds and event densities." Journal of Archaeological Science 38(9):2116-22.

Cann RL, Stoneking M, Wilson AC. 1987. Mitochondrial DNA and human evolution. Nature 325(6099):31-6.

Chen FH, Bloemendal J, Wang JM, Li JJ, Oldfield F. 1997. High-resolution multi-proxy climate records from Chinese loess: evidence for rapid climatic changes over the last $75 \mathrm{kyr}$. Palaeogeography, $\mathrm{Pa}$ laeoclimatology, Palaeoecology 130(1-4):323-35.

Chen FH, Bloemendal J, Feng ZD, Wang JM, Parker E, Guo ZT. 1999. East Asian Monsoon variations during Oxygen Isotope Stage 5: evidence from the northwestern margin of the Chinese Loess Plateau. Quaternary Science Reviews 18(8-9):1127-35.

Chen T, Yuan S. 1988. Uranium-series dating of bones and teeth from Chinese Paleolithic sites. Archaeom- etry 30(1):59-76.

Chen T, Yuan S, Gao S. 1984. Uranium-series dating of bones and teeth from Chinese Paleolithic sites. Acta Anthropologica Sinica 3:259-69.

Cheon KH, Lee YJ. 2008. A study of lithic assemblage from the Yong-Bang Paleolithic site. Journal of the Korean Paleolithic Society 17:17-32. In Korean.

Chinese Quaternary Research Association (CQRA). 1987. Contributions to Quaternary Glaciology and Geology. Special Issue on ${ }^{14} \mathrm{C}$ Dating. In Chinese.

Choi BK. 2007. A study on the Hwadae-ri Shomteo Paleolithic site in Pocheon-city, Korean Peninsula. Journal of the Korean Paleolithic Society 15:57-68. In Korean.

Chu JY, Huang W, Kuang SQ, Wang JM, Xu JJ, Chu ZT, Yang ZQ, Lin KQ, Li P, Wu M, Geng ZC, Tan CC, Du RF, Jin L. 1998. Genetic relationship of populations in China. Proceedings of the National Academy of Sciences of the USA 95(20):11,763-8.

d'Errico F. 2003. The invisible frontier. A multiple species model for the origin of behavioural modernity. Evolutionary Anthropology 12(4):188-202.

Damblon F, Haesaerts P, van der Plicht J. 1996. New datings and considerations on the chronology of Upper Palaeolithic sites in the Great Eurasiatic Plain. Préhistoire Européenne 9:177-231.

Derevianko AP. 1998. Human occupation of nearby regions and the role of population movements in the Paleolithic of Siberia. In: Derevianko AP, editor. The Paleolithic of Siberia, New Discoveries and Interpretations. Urbana: University of Illinois Press. p 336-80.

Derevianko AP, Agadjanian AK, Baryshnikov GF, Dergacheva MI, Malaeva EM, Markin SV, Molodin VI, Nikolaev SV, Orlova LA, Petrin VT, Postnov AV, Ulanov VA, Fedeneva IK, Foronova IV, Shunkov MV. 1998. Archaeology, Geology and the Pleistocene and Holocene Paleogeography of the Mountainous Altai. Novosibirsk: Institute of Archaeology and Ethnology Press.

Derevianko AP, Brantingham PJ, Olsen JW, Tseveendorj D. 2004. Initial Upper Paleolithic blade industries from the North-central Gobi Desert, Mongolia. In: Brantingham PJ, Kuhn SL, Kerry KW, editors. The Early Upper Paleolithic Beyond Western Europe. Los Angeles: University of California Press. p 207-22.

Derevianko AP, Postnov AV, Rybin EP, Kuzmin YV, Keates SG. 2005. The Pleistocene peopling of Siberia: a review of environmental and behavioral aspects. Bulletin of the Indo-Pacific Prehistory Association 25:57-68.

Drozdov NI, Laukhin SA, Chekha VP, Koltsova VG, Bokarev AA, Vikulov AA. 1990. Kurtakski Arkheologicheski Raion. Vyp. I. Geologiya i Arkheologiya Trifonovskogo $i$ Kurtakskogo Uchastkov. Krasnoyarsk: Izdatelstvo Instituta Istorii, Arkheologii i Etnografii.

Gamble C, Davies W, Pettitt P, Hazelwood L, Richards M. 2005. The archaeological and genetic founda- 
tions of the European population during the Late Glacial: implications for 'agricultural thinking'. Cambridge Archaeological Journal 15(2):193-223.

Gao X, Norton CJ. 2002. A critique of the Chinese 'Middle Palaeolithic.' Antiquity 76(292):397-412.

Gao X, Li JZ, Madsen DB, Brantingham PJ, Elston RG, Bettinger RL. 2002. New ${ }^{14} \mathrm{C}$ dates for Shuidonggou and related discussions. Acta Anthropologica Sinica 21:211-8. In Chinese with English abstract.

Gao X, Yuan B, Pei S, Wang H, Chen F, Feng X. 2008. Analysis of sedimentary-geomorphologic variation and the living environment of hominids at the Shuidonggou Paleolithic site. Chinese Science Bulletin 53(13):2025-32.

Geng K, Dan P. 1992. The Yinchuan Area: Past, Present, and Future-Processes of Late Quaternary Environmental Evolution. Beijing: Cartographic Publishing House. In Chinese.

Ginter BJ, Kozlowski JK, Laville H, Sirakov N, Hedges REM. 1996. The transition in the Balkans: news from Temnata Cave, Bulgaria. In: Carbonell E, Vaquero M, editors. The Last Neanderthals, the First Anatomically Modern Humans: A Tale About Human Diversity, Cultural Change and Human Evolution: The Crisis and 40,000 B.P. Tarrogona: Universitat de Rovira i Virgili. p 169-200.

Goebel T. 1993. The Middle to Upper Paleolithic transition in Siberia [unpublished $\mathrm{PhD}$ dissertation]. Department of Anthropology, University of Alaska Fairbanks.

Goebel T. 2004. The Early Upper Paleolithic of Siberia. In: Brantingham PJ, Kuhn SL, Kerry KW, editors. The Early Upper Paleolithic Beyond Western Europe. Los Angeles: University of California Press. p 162-95.

Goebel T, Aksenov M. 1995. Accelerator radiocarbon dating of the Initial Upper Palaeolithic in Southeas Siberia. Antiquity 69(263):349-57.

Goebel T, Derevianko AP, Petrin VT. 1993. Dating the Middle-to-Upper-Paleolithic transition at $\mathrm{Ka}$ ra-Bom. Current Anthropology 34(4):452-8.

Goring-Morris AN, Belfer-Cohen A, editors. 2005. More than Meets the Eye: Studies on the Upper Palaeolithic Diversity in the Near East. Oxford: Oxbow Books.

Graf KE. 2008. "The good, the bad, and the ugly": evaluating the radiocarbon chronology of the Middle and Late Upper Paleolithic in the Enisei River Valley, South-Central Siberia. Journal of Archaeological Science 36(3):694-707.

Guan Y, Gao X, Wang H, Chen F, Pei S, Zhang X, Zhou Z. 2011. Spatial analysis of intra-site use at a Late Paleolithic site at Shuidonggou, Northwest China. Chinese Science Bulletin 56(32):3457-63.

Guan Y, Gao X, Li F, Pei S, Chen F, Zhou Z. 2012. Modern human behaviors during the late stage of the MIS3 and the broad spectrum revolution: evidence from a Shuidonggou Late Paleolithic site. Chinese Science Bulletin 57(4):379-86.

Haesaerts P. 1990. Nouvelles recherches au Gisement de
Willendorf (Basse Autriche). Bulletin de l'Institut Royal des Sciences Naturelles de Belgique, Sciences de la Terre 60:203-18.

Haesaerts P, Damblon F, Bachner M, Trnka G. 1996. Revised stratigraphy and chronology of the Willendorf II sequence, Lower Austria. Archaeologia Austriaca 80:24-9.

Han CG. 2002. Yongho-dong Paleolithic site at Daejeon, Korea. In: Bae K, Lee J, editors. Paleolithic Archaeology in Northeast Asia: Assembled Collection of Papers Presented at the International Seminar Commemorating the Tenth Chongokni Prehistoric Festival. Hanyang University: Yeoncheon County and Institute of Cultural Properties. p 163-72.

Hedges REM, Housley RA, Bronk Ramsey C, van Klinken GJ. 1994. Radiocarbon dates from the Oxford AMS system: Archaeometry datelist 18. Archaeometry 36(2):337-74.

Henshilwood CS, Marean CW. 2003. The origin of modern human behavior: critique of models and their test implications. Current Anthropology 44(5):627-51.

Higham T. 2011. European Middle and Upper Palaeolithic radiocarbon dates are often older than they look: problems with previous dates and some remedies. Antiquity 85(327):235-49.

Hong MY, Kim JH. 2008. Hopyeong-dong Paleolithic Site. Suwon: Korea Land Corporation, Gyeonggi Cultural Foundation and Gijeon Institute of Cultural Properties.

Ingman M, Kaessmann H, Paabo S, Gyllensten U. 2000. Mitochondrial genome variation and the origin of modern humans. Nature 408(6828):708-13.

Jöris O, Street M, Terberger T, Weninger B. 2011. Radiocarbon dating the Middle to Upper Palaeolithic transition: the demise of the last Neanderthals and the first appearance of anatomically modern humans in Europe. In: Condemi S, Weninger G-C, editors. Continuity and Discontinuity in the Peopling of Europe. Dordrecht: Springer. p 239-98.

Klein RG. 2008. Out of Africa and the evolution of modern human behavior. Evolutionary Anthropology 17(6):267-81

Konstantinov MV. 1994. Kamennyi Vek Vostochnogo Regiona Baikal'skoi Azii. Chita: Chita Pedagogical University Press.

Kuhn SL. 2004. From Initial Upper Paleolithic to Ahmarian at Üçağizli Cave, Turkey. Anthropologie 42(3):249-62.

Kuhn SL, Stiner MC, Gülec E. 1999. Initial Upper Paleolithic in south-central Turkey and its regional context: a preliminary report. Antiquity 73(281):505-17.

Kuhn SL, Brantingham PJ, Kerry KW. 2004. The early Upper Paleolithic and the origins of modern human behavior. In: Brantingham PJ, Kuhn SL, Kerry KW, editors. The Early Upper Paleolithic Beyond Western Europe. Los Angeles: University of California Press. p 242-8.

Kuhn SL, Stiner MC, Güleç E, Özer I, Yılmaz H, Baykara I, Açıkkol A, Goldberg P, Molina KM, Ünay E, Suata-Alpaslan F. 2009. The early Upper Paleolithic 
occupations at Üçağızlı Cave (Hatay, Turkey). Journal of Human Evolution 56(2):87-113.

Kuzmin YV. 1994. Prehistoric colonization of Northeastern Siberia and migration to America: radiocarbon evidence. Radiocarbon 36(3):367-76.

Kuzmin YV. 2004. Origin of the Upper Paleolithic in Siberia. In: Brantingham PJ, Kuhn SL, Kerry KW, editors. The Early Upper Paleolithic Beyond Western Europe. Los Angeles: University of California Press. p 196-206.

Kuzmin YV, Orlova LA. 1998. Radiocarbon chronology of the Siberian Paleolithic. Journal of World Prehistory $12(1): 1-53$.

Lee GK. 2004. Wolpyong, a typical Upper Paleolithic site in Suncheon, Korea. Journal of the Korean Paleolithic Society 9:1-18. In Korean.

Li F, Kuhn SL, Gao X, Chen F. 2013. Re-examination of the dates of large blade technology in China: a comparison of Shuidonggou Locality 1 and Locality 2. Journal of Human Evolution 64(2):161-8.

Li X, Liu G, Xu G. 1987. Dating reports on the ${ }^{14} \mathrm{C}$ methodology (PV). In: Radiocarbon Dating Society of Chinese Quaternary Research Association, editor. Contribution to the Quaternary Glaciology and Geology. Beijing: Geological Publishing House. p 16-38. In Chinese.

Licent E, Chardin P. 1925. Le Paléolithique de la Chine. L'Anthropologie 35:201-34.

Lisitsyn NF, Svezhentsev YS. 1997. Radiocarbon chronology of the Upper Paleolithic of Northern Asia. In: Sinitsyn AA, Praslov ND, editors. Radiouglerodnaya Chronologia Paleolita Vostochonoi Europy i Severnoi Azii: Problemy i Perspectivy. St. Petersburg: Institute for the History of Material Culture. p 67-100.

Liu D, Wang X, Gao X, Xia Z, Pei S, Chen F, Wang H. 2009. Progress in the stratigraphy and geochronology of the Shuidonggou site, Ningxia, North China. Chinese Science Bulletin 54(21):3880-6.

Madsen DB, Li J, Brantingham PJ, Gao X, Elston RG, Bettinger RL. 2001. Dating Shuidonggou and the Upper Palaeolithic blade industry in North China. Antiquity 75(290):706-16.

Marks AE. 1983. Prehistory and Paleoenvironment in the Negev, Israel. Dallas: Southern Methodist University Press.

Medvedev G, Cauwe N, Vorobieva G, Coup D, Claes L, Lipnina E, Modri S, Mukharramov S, Osadchy S, Pettitt P, Rebrikov P, Rogovsky E, Sitlivy V, Sulerzhitsky L, Khenzykhenova F. 1996. The Malta Paleolithic Locality (According to the 1995 Fieldseason). Irkutsk: Arcon.

Meignen L, Geneste JM, Koulakovskaia L, Sytnik A. 2004. Koulichivka and its place in the Middle-Upper Paleolithic transition in Eastern Europe. In: Brantingham PJ, Kuhn SL, Kerry KW, editors. The Early Upper Paleolithic Beyond Western Europe. Los Angeles: University of California Press. p 50-63.

Mellars P. 1999. The Neanderthal problem continued. Current Anthropology 40(3):341-60.
Millard AR, Hedges REM. 1995. The role of the environment in uranium uptake by buried bone. Journal of Archaeological Science 22(2):239-50.

Mook WG. 1982. Radiocarbon dating. In: Kozlowski $\mathrm{JK}$, editor. Excavation in the Bacho Kiro Cave (Bulgaria): Final Report. Warsaw: Polish Scientific Publishers. p 168.

Morgan C, Barton L, Bettinger R, Chen F, Dongju Z. 2011. Glacial cycles and Palaeolithic adaptive variability on China's Western Loess Plateau. Antiquity 85(328):365-79.

Muratov VM, Ovodov ND, Panychev VA, Safrova SA. 1982. Obshchaia kharakteristika Paleolitichekoi Stoianki Malaia Syia v Khakasii. Arkheologiia Svenoi Azii. Novosibirsk: Nauka. p 33-48.

Murray AS, Olley JM. 2002. Precision and accuracy in the optically stimulated luminescence dating of sedimentary quartz: a status review. Geochronometria 21:1-16.

Ningxia Museum 1987. A report on the 1980 excavations at Shuidonggou. Kaogu 10:439-49. In Chinese.

Ningxia Provincial Institute of Archaeology. 2003. Shuidonggou - 1980 Excavation Report. Beijing: Science Press. In Chinese.

Norton CJ, Jin JH. 2009. The evolution of modern human behavior in East Asia: current perspectives. Evolutionary Anthropology 18(6):247-60.

O'Connell JF, Allen J. 2004. Dating the colonization of Sahul (Pleistocene Australia-New Guinea): a review of recent research. Journal of Archaeological Science 31(6):835-53.

Orlova LA. 1995. Radiouglerodnoye Datirovanie Arkheologichesikh Pamiatnikov Siberi i Dalnego Vostoka. In: Derevianko AP, Kholushkin YP, editors. Metody Estestvennykh Nauk v Arkheologicheskikh Rekonstruktsiyakh. Novosibirsk: Izdatelstvo Instituta Arheologii i Ethnografii SORAN. p 207-32.

Orlova LA. 1998. Radiocarbon dating of the archaeology sites in Siberia and the Russian Far East: List 2. In: Derevianko AP, Kholushkin YP, Rostovtsev OS, Voronin VT, editors. Statistical Analysis of the Upper Paleolithic Complexes of Northern Asia, Supplement. Novosibirsk: Institute of Archaeology and Ethnology Press. p 74-88.

Pei S, Gao X, Wang H, Kuman K, Bae CJ, Chen F, Guan Y, Zhang Y, Zhang X, Peng F, Li X. 2012. The Shuidonggou site complex: new excavations and implications for the earliest Late Paleolithic in north China. Journal of Archaeological Science 39(12):3610-26.

Peng F, Gao X, Wang H, Chen F, Liu D, Pei S. 2012. An engraved artifact from Shuidonggou, an early Late Paleolithic site in northwest China. Chinese Science Bulletin 57(1):1-6.

Pettitt PB, Davies W, Gamble CS, Richards MB. 2003. Palaeolithic radiocarbon chronology: quantifying our confidence beyond two half-lives. Journal of Archaeological Science 30(12):1685-93.

Pike AWG, Hedges REM. 2001. Sample geometry and U-uptake in archaeological teeth: implications for 
U-series and ESR dating. Quaternary Science Reviews 20(5-9):1031-9.

Qu T, Bar-Yosef O, Wang Y, Wu X. 2013. The Chinese Upper Paleolithic: geography, chronology, and techno-typology. Journal of Archaeological Research 21(1):1-73.

Rae A, Hedges REM, Ivanovich M. 1989. Further studies for uranium-series dating of fossil bones. Applied Geochemistry 4(3):331-7.

Reich D, Patterson N, Kircher M, Delfin F, Nandineni Madhusudan R, Pugach I, Ko Albert M-S, Ko Y-C, Jinam TA, Phipps Maude E, Saitou N, Wollstein A, Kayser M, Pääbo S, Stoneking M. 2011. Deni sova admixture and the first modern human dispersals into Southeast Asia and Oceania. The American Journal of Human Genetics 89(4):516-28.

Reimer PJ, Baillie MGL, Bard E, Bayliss A, Beck JW, Blackwell PG, Bronk Ramsey C, Buck CE, Burr GS, Edwards RL, Friedrich M, Grootes PM, Guilderson TP, Hajdas I, Heaton TJ, Hogg AG, Hughen KA, Kaiser KF, Kromer B, McCormac FG, Manning SW, Reimer RW, Richards DA, Southon JR, Talamo S, Turney CSM, van der Plicht J, Weyhenmeyer CE. 2009. IntCa109 and Marine09 radiocarbon age calibration curves, 0-50,000 years cal BP. Radiocarbon 51(4):1111-50.

Richter D, Tostevin G, Škrdla P. 2008. Bohunician technology and thermoluminescence dating of the type locality of Brno-Bohunice (Czech Republic). Journal of Human Evolution 55(5):871-85.

Seong C. 2006. A comparative and evolutionary approach to the Korean Paleoithic assemblages. Journal of Korean Ancient Historical Society 51:5-42.

Seong C. 2008. Tanged points, microblades and Late Palaeolithic hunting in Korea. Antiquity 82(308):81783.

Seong C. 2009. Emergence of a blade industry and evolution of Late Paleolithic technology in the Republic of Korea. Journal of Anthropological Research 65(3):417-51.

Seong C. 2011. Evaluating radiocarbon dates and Late Paleolithic chronology in Korea. Arctic Anthropology 48(1):93-112.

Shea JJ. 2011. Homo sapiens is as Homo sapiens was. Current Anthropology 52(1):1-35.

Shennan S, Edinborough K. 2007. Prehistoric population history: from the Late Glacial to the Late Neolithic in central and northern Europe. Journal of Archaeological Science 34(8):1339-45.

Škrdla P, Tostevin G. 2005. Brno-Bohunice, analysis of material from the 2002 excavation. Př ehed vyzzkumu 46:35-61.

Steele J. 2010. Radiocarbon dates as data: quantitative strategies for estimating colonization front speeds and event densities. Journal of Archaeological Science 37(8):2017-30.

Steier P, Rom W. 2000. The use of Bayesian statistics for ${ }^{14} \mathrm{C}$ dates of chronologically ordered samples: a critical analysis. Radiocarbon 42(2):183-98.

Stuiver M, Reimer PJ. 1993. Extended ${ }^{14} \mathrm{C}$ data base and revised CALIB $3.0{ }^{14} \mathrm{C}$ age calibration program. $R a$ diocarbon 35(1):215-30.

Su B, Xiao C, Deka R, Seielstad MT, Kangwanpong D, Xiao J, Lu D, Underhill P, Cavalli-Sforza L, Chakraborty R, Jin L. 2000. Y chromosome haplotypes reveal prehistoric migrations to the Himalayas. Human Genetics 107(6):582-90.

Sun J, Zhao Z. 1991. Quaternary Geology in the Loess Plateau. Beijing: Science Press. In Chinese.

Svoboda JA. 2003. Chronostratigraphic background, environment, and formation of the archaeological layers. In: Svoboda J, Bar-Yosef O, editors. Stránská skála: Origins of the Upper Paleolithic in the Brno Basin. Cambridge: American School of Prehistoric Research, Bulletin 47. Dolni Vestonice Publications 10. Peabody Museum Publications. p 15-26.

Svoboda JA. 2004. Continuities, discontinuities, and interactions in Early Upper Paleolithic technologies: a view from the Middle Danube. In: Brantingham PJ, Kuhn SL, Kerry KW, editors. The Early Upper Paleolithic Beyond Western Europe. Los Angeles: University of California Press. p 30-49.

Usik VI, Monigal K, Kulakovskaya L. 2006. New perspectives on the Transcarpathian Middle to Upper Paleolithic boundary. In: Conard NJ, editor. When Neanderthals and Modern Humans Met. Tübingen: Kerns Verlag. p 213-32.

Valoch K, editor. 1976. Die Altsteinzeitliche Fundstelle in Brno-Bohunice. Prague: Academia.

van Andel TH. 2005. The ownership of time: approved ${ }^{14} \mathrm{C}$ calibration or freedom of choice? Antiquity 79(306):944-8.

van Andel TH, Davies W, Weninger B, Jöris O. 2003. Archaeological dates as proxies for the spatial and temporal human presence in Europe: a discourse on the method. In: van Andel TH, Davies W, editors. Neanderthals and Modern Humans in the European Landscape during the Last Glaciation: Archaeological Results of the Stage 3 Project. Cambridge: McDonald Institute for Archaeological Research. p 21-9.

Vasiliev SS. 1992. The Late Paleolithic of the Yenisei: a new outline. Journal of World Prehistory 6(3):33783.

Vishnyatsky LB, Nehoroshev PE. 2004. The beginning of the Upper Paleolithic on the Russian Plain. In: Brantingham PJ, Kuhn SL, Kerry KW, editors. The Early Upper Paleolithic Beyond Western Europe. Los Angeles: University of California Press. p 8096.

Vogel JS, Southon JR, Nelson DE, Brown TA. 1984. Performance of catalytically condensed carbon for use in accelerator mass spectrometry. Nuclear Instruments and Methods in Physics Research B 5(2):289-93.

Wang C, Zhang Y, Gao X, Zhang X, Wang H. 2009. Archaeological study of ostrich eggshell beads collected from SDG site. Chinese Science Bulletin 54(21):3887-95.

Weninger B, Jöris O. 2008. A ${ }^{14} \mathrm{C}$ age calibration curve 
for the last $60 \mathrm{ka}$ : the Greenland-Hulu U/Th timescale and its impact on understanding the Middle to Upper Paleolithic transition in Western Eurasia. Journal of Human Evolution 55(5):772-81.

Weninger B, Edinborough K, Clare L, Jöris O. 2011. Concepts of probability in radiocarbon analysis. Documenta Prehistorica 38:1-20.

Weninger B, Jöris O, Danzeglocke U. 2012. CalPal-2007. Cologne Radiocarbon Calibration \& Palaeoclimate Research Package. http://www.calpal. de/. Accessed 30 January 2012.

Williams AN. 2012. The use of summed radiocarbon probability distributions in archaeology: a review of methods. Journal of Archaeological Science 39(3):578-89.

Wu X. 2004. On the origin of modern humans in China. Quaternary International 117(1):131-40.

Yang JS, Hong MY, Kim JR, Kim NH, Mo HS, Kim JH.
2008. Excavation Report No. 18, the Deokso Site, Nayangju, Gyeonggi Province, Korea. University of Suwon Museum. In Korean.

Zam'atnin SN. 1951. O Vozniknovenii Lokal'nykh Razlichiy v Kul'ture Paleoliticheskogo Perioda (On the Appearance of Local Differences in the Culture of the Paleolithic Period). Prosiskhozhdenie i Rasselenie Chelovechestva. Trudy Insituta Etntografi. p 89-152.

Zhang D, Chen FH, Bettinger RL, Barton L, Ji DX, Morgan CT, Wang H, Chen XZ, Dong GH. 2010. Archaeological records of Dadiwan in the past $60 \mathrm{ka}$ and the origin of millet agriculture. Chinese Science Bulletin 55(16):1636-42.

Zhang F, Su B, Zhang Y-P, Jin L. 2007. Genetic studies of human diversity in East Asia. Philosophical Transactions of the Royal Society 362(1482):987-96. 